\title{
EFFECTS OF DEXAMETHASONE ON CONTRALATERAL TESTICULAR IMMUNE RESPONSE IN WISTAR STRAIN RATS WITH UNILATERAL TESTICULAR TORSION
}

\author{
Andri Kustono ${ }^{1}$, Ketut Sudiana ${ }^{2}$, Fikri Rizaldi ${ }^{1}$, Tarmono ${ }^{1}$ \\ ${ }^{1}$ Department of Urology, ${ }^{2}$ Department of Anatomic Pathology, Faculty of Medicine, Universitas Airlangga, \\ Dr. Soetomo Hospital, Surabaya
}

\begin{abstract}
ABSTRAK
Tujuan penelitian ini adalah untuk membuktikan pengaruh pemberian deksametason terhadap respon imun pada tikus dengan torsio testis. Penelitian ini merupakan penelitian eksperimental dengan post test only control group design. Pada penelitian ini sebanyak 27 ekor tikus secara random dibagi menjadi 3 kelompok. Pada kelompok normal atau sham orkhidektomi dilakukan pada testis kanan pada hari ke-14 (CN). Kelompok kontrol positif mengalami torsio testis selama 10 jam, kemudian detorsi manual dilakukan setelah 4 jam, dan pada hari ke-14 dilakukan orkhidektomi pada testis ipsilateral dan kontralateral (CP). Kelompok perlakuan mengalami torsio testis 10 jam dan mendapat deksametason $10 \mathrm{mg} / \mathrm{kgBB} / \mathrm{subkutan} 30$ menit sebelum dilakukan detorsi manual 4 jam kemudian, dan pada hari ke-14 dilakukan orkhidektomi pada testis ipsilateral dan kontralateral (N). Jumlah spermatogonium dihitung berdasarkan rata-rata jumlah penampang tubulus seminiferus di intratubuler yang diamati pada 10 penampang sayatan testis kontralateral dengan pewarnaan Haematoxiliyn Eosin (HE). Jumlah IgG dihitung berdasarkan rata-rata jumlah tubulus seminiferus di ekstratubuler yang diamati pada 5 penampang sayatan testis kontralateral dengan pewarnaan imunohistokimia (IHC). Jumlah spermatogonium berbeda bermakna antara kelompok $C N$ dan $C P, C N$ dan $N$, maupun $C P$ dan $N(p<0,05)$. Produksi IgG juga menunjukkan perbedaan bermakna antara $C N$ dan $C P, C N$ dan $N$, maupun $C P$ dan $N(p<0,05)$. Sebagai simpulan, pemberian deksametason memberikan efek proteksi terhadap jumlah spermatogonium dan produksi IgG pada torsio testis 10 jam. (FMI 2018;54:29-33)
\end{abstract}

Kata kunci: Deksametason; torsio testis; spermatogonium; $\operatorname{Ig} G$

\begin{abstract}
The aim of this study was to prove the effects of dexamethasone on immune responses in rats with testicular torsion. This was an experimental study with post test only control group design. In this study, 27 rats were randomly divided into 3 groups. In normal or sham group $(C N)$ orchidectomy was performed on the right testis on day 14. The positive control group $(C P)$ had testicular torsion for $10 \mathrm{~h}$, then manual detorsion was performed after $4 \mathrm{~h}$, and on day 14 orchidectomy was performed on ipsilateral and contralateral testes. The treatment group $(\mathrm{N})$ had testicular torsion for $10 \mathrm{~h}$ and received $10 \mathrm{mg} / \mathrm{kgBW}$ dexamethasone subcutaneously $30 \mathrm{minutes}$ before manual detorsion 4 hours later, and on day 14 orchidectomy was performed to ipsilateral and contralateral testes. The spermatogonium count was calculated based on the average number of intratubular seminiferous tubule section observed in contralateral testicular incision with Haematoxiliyn Eosin (HE) staining. IgG count was calculated based on the average number of extratubular seminiferous tubules observed at 5 contralateral testicular incision with immunohistochemical staining (IHC). The number of spermatogonia was significantly different between $C N$ and $C P, C N$ and $N$, and $C P$ and $N(p<0.05)$. IgG production also showed significant differences between $C N$ and $C P, C N$ and $N$, as well as $C P$ and $N(p<0.05)$. In conclusion, administration of dexamethasone provides a protective effect on spermatogonium count and IgG production on a 10-hour testicular torsion. (FMI 2018;54:29-33)
\end{abstract}

Keywords: Dexamethasone; testicular torsion; spermatogonium; IgG

Correspondence: Andri Kustono, Department of Urology, Faculty of Medicine, Universitas Airlangga, Dr. Soetomo Hospital, Surabaya. Jl. Mayjen Prof. Dr. Moestopo 6-8 Surabaya 60286. Phone: +62 31 5501318; Fax: +62 315024971

\section{INTRODUCTION}

Testicular torsion is a condition in which the twisted spermatic cord results in occlusion and strangulation of the venous or arterial vascularization to the testes and epididymis. Testicular torsion is a state of emergency and requires immediate surgery. This condition, if not treated promptly within 4 to 6 hours after the onset of pain, may lead to testicular infarction which will then be followed by testicular atrophy (Sjamsuhidajat \& De
Jong 2004). Testicular torsion is also the most common urological emergency in young adult males, with an incidence rate of 1 in 4000 people under 25 years of age and most commonly suffered by young males at puberty (12-20 years) (Purnomo 2003). The most common causes of loss of the testis after torsion is the delay in seeking treatment $(58 \%)$, errors in initial diagnosis (29\%), and therapy delay (13\%) (Cuckow \& Frank 2000). 
Surgery in the form of detorsion should be done immediately after the diagnosis of testicular torsion is established or suspicion of the presence of testicuar torsion (Subowo 1993). The number of testicular torsion cases and those successfully reversed in Surabaya until 1990 was still low at around $28 \%$. The low number of testicular viability is due to the delay of the patient coming to the hospital. As many as $74 \%$ of the patients came to the hospital more than 24 hours after experiencing testicular torsion (Purnomo 2003). Torsion duration greatly affects the viability of the testes. If the torsion occurs less than 3 hours until detection is done, the viability reaches $100 \%$. If it lasts for 8 hours, the testicular viability decreases to $75 \%$, and if the torsion lasts more than 24 hours, the testes are rarely still viable (Barker \& Raper 1964).

The twisting of one of the spermaticus cords of the testis causes occlusion and resistance of blood vessel flow to the testicles, causing testicular cells to experience hypoxia and anoxia. These anoxic sertoli cells can damage bloodstream system in the testes and stimulate germinal epithelial cells to release proteins into blood circulation by immunocompetent cells as autoantigens that trigger immune response. Furthermore, the differentiation and activation of these $\mathrm{T}$ cells can secrete various cytokines. IL-4 cytokine induces the activation, proliferation, and maturation of B lymphocytes, thus differentiating into plasma cells produced by immunoglobulin $\mathrm{G}$ where the plasma cells produce antibodies that can cause damage to germinal epithelial cells in contralateral testes (Hardjowijoto 2004). Antigens antibody complex activate complement, resulting in lysis within target cells and replaced with connective tissue (Turek 1997). IgG has a smaller size and molecular mass than IgM so it is possible to penetrate blood barrier more easily than $\operatorname{IgM}$. IgG is more specific to chronic disease processes. The period of $\mathrm{IgG}$ formation is about 14 days, whereas $\operatorname{IgM}$ is more specific to the acute disease process and the formation period is about 3 days (Subowo 1993).

Impaired spermatogenesis function in contralateral testis of patients with unilateral testicular torsion is thought to be influenced by autoimmune reaction, as that in squestered antigen theory. This theory explains that all embryonic tissues have been reached by immune response, so the tissue is known as itself. However, in embryonal times there are tissues that are not reached by the response (eg spermatozoa). This happens because there is a broken barrier. As a result, the spermatozoa is reached by the immune system as a foreign body so as to trigger an immune response characterized by antibody formation (Subowo 1993).
Dexamethasone is a synthetic glucocorticoid steroid drug used as a powerful anti-allergic, immunosuppressant, anti-inflammatory and anti-shock agent. The drug is 20-30 times stronger than hydrocortisone and 5-7 times stronger than prednisone. As an anti-inflammatory drug, it suppresses neutrophil migration, reduces prostaglandin production (a compound that acts as an inflammatory mediator), and causes capillary dilatation. This will reduce the body's response to inflammatory conditions (Doerge 1982, Saez et al 1977). The aim of this study was to prove the effect of dexamethasone on immune responses in rats with testicular torsion.

\section{MATERIALS AND METHODS}

This study was an experimental study using post test only control group design. In this study, 27 rats were randomly divided into 3 groups. In the normal or sham group $(\mathrm{CN})$ orchidectomy was performed on the right testis on day 14. In positive control group (CP), testicular torsion was performed for 10 hours, then manual detorsion was performed 4 hours thereafter. Orchidectomy of the ipsilateral and contralateral testes was performed on day 14. In the treatment group $(\mathrm{N})$, testicular torsion was performed for 10 hours, receiving $10 \mathrm{mg} / \mathrm{kgBW}$ dexamethasone subcutaneously 30 minutes before manual detection 4 hours later, and orchidectomy on ipsilateral and contralateral testes was performed on day 14. The spermatogonium count was calculated based on the average number of intratubular seminiferous tubular sections observed on 10 crosssections of contralateral testicle incision with Haematoxiliyn Eosin (HE) staining. The amount of $\mathrm{IgG}$ was calculated based on the average number of extratubular seminiferous tubules observed in 5 cross-sections of contralateral testis with immunohistochemical staining (IHC).

\section{RESULTS}

\section{Data characteristics}

The average contralateral spermatogonium and $\mathrm{IgG}$ counts in the Wistar-strain rats after treatment are shown in Table 1 and 2.

Table 1. Mean spermatogonium counts in $\mathrm{CN}, \mathrm{CP}, \mathrm{N}$

\begin{tabular}{cll}
\hline Groups & n & Mean \\
\hline CN & 9 & 97.42 \\
CP & 9 & 40.24 \\
N & 9 & 60.99 \\
\hline
\end{tabular}


Tabel 2. Percentages (\%) of $\mathrm{IgG}$ in $\mathrm{CN}, \mathrm{CP}, \mathrm{N}$

\begin{tabular}{ccc}
\hline Groups & $\mathrm{n}$ & Mean \\
\hline $\mathrm{CN}$ & 9 & 1.54 \\
$\mathrm{CP}$ & 9 & 58.48 \\
$\mathrm{~N}$ & 9 & 30.61 \\
\hline
\end{tabular}

\section{Effects of dexamethasone administration on spermatogonium cells}

Statistical test using Shapiro-Wilk test showed that spermatogonia count in each group had normal distribution $(p>0.05)$. Variance test showed that each group was homogeneous $(\mathrm{p}>0.05)$, qualifying the use of parametric test. Therefore, data were analyzed using ANOVA test (Table 3).

Table 3. Comparison of spermatogonium count in $\mathrm{CN}$, $\mathrm{CP}, \mathrm{N}($ mean $\pm \mathrm{SD})$

\begin{tabular}{cccc}
\hline Groups & $\mathrm{n}$ & $\begin{array}{c}\text { Spermatogonium } \\
\text { counts }\end{array}$ & $\mathrm{p}$ \\
\hline $\mathrm{CN}$ & 9 & $97.42 \pm 14.34$ & $0.00^{*}$ \\
$\mathrm{CP}$ & 9 & $40.24 \pm 22.34$ & \\
$\mathrm{~N}$ & 9 & $60.99 \pm 8.41$ & \\
\hline
\end{tabular}

Statistical analysis showed $\mathrm{p}<0.05$, indicating significant differences between groups. Therefore, the analysis continued with the Post-Hoc Tukey test to determine the differences of each group (Table 4).

Table 4. Tukey's Post-Hoc analysis of the comparison of spermatogonium count

\begin{tabular}{lcccc}
\hline \multirow{2}{*}{$\begin{array}{c}\text { Comparison } \\
\text { between Groups }\end{array}$} & Mean & \multicolumn{2}{c}{ IK 95\% } & \multirow{2}{*}{ difference } \\
\cline { 3 - 4 } & Min & Max & \\
\hline CN VS CP & 57.17 & 38.25 & 76.11 & 0.00 \\
CN VS N & 36.43 & 17.50 & 55.36 & 0.00 \\
CP VS N & $-20,74$ & -39.67 & -1.82 & 0.03 \\
\hline
\end{tabular}

Table 4 shows that in groups undergoing contralateral testicular torsion for $10 \mathrm{~h}$, then manual detorsion (CP), a significant decrease in spermatogonium cell count $(\mathrm{p}<0.05)$ is found compared with that in non-torsion group $(\mathrm{CN})$. The group that experienced torsion for 10 hours and received dexamethasone 30 minutes before manual detorsion $(\mathrm{N})$ showed significant effect ( $\mathrm{p}$ $<0.05$ ) on the prevention of spermatogonium cell count decrease compared to group having testicular torsion for 10 hours and then subjected to manual detorsion (CP).

However, the administration of dexamethasone has not been able to maintain spermatogonium levels within normal limits as the group not subjected to torsion (CN) ( $\mathrm{p}<0.05$ ). Therefore, it can be concluded that the administration of dexamethasone prior to manual detorsion can provide a protective effect in preventing the decrease in spermatogonium cell count in the testes whose contralateral side undergoes testicular torsion lasting for 10 hours.

\section{Effects of dexamethasone administration on IgG production}

Statistical test using Shapiro-Wilk test showed that the number of sertoli cells in each group had no normal distribution $(\mathrm{p}<0.05)$ and the variance test of each group was not homogeneous $(\mathrm{p}<0.05)$, so the requirement of parametric test was not met. Therefore, the data were analyzed using Kruskall-Walis test.

Table 5. Difference in percentage (\%) of IgG production on $\mathrm{CN}, \mathrm{CP}$, and N. Data presented in median, minimum-maximum

\begin{tabular}{lcccc}
\hline Groups & $\mathrm{n}$ & Median & Minimum-Maximum & $\mathrm{p}$ \\
\hline $\mathrm{CN}$ & 9 & 1.01 & $0.51-4.72$ & $0.00 *$ \\
$\mathrm{CP}$ & 9 & 56.42 & $46.08-72.86$ & \\
$\mathrm{~N}$ & 9 & 27.70 & $10.03-52.25$ & \\
\hline
\end{tabular}

Statistical analysis using Kruskall Walis test showed $\mathrm{p}<0.05$, showing significant differences between groups. The analysis continued with Post-Hoc Mann-Whitney U test to determine the differences of each group (Table 6). The results of Mann-Whitney U Post-Hoc test in Table 6 show the difference in percentage of $\mathrm{IgG}$ levels in non-torsion group $(\mathrm{CN})$ from the group undergoing contralateral testicular torsion for $10 \mathrm{~h}$ and then subjected to manual detorsion $(\mathrm{CP})(\mathrm{p}<0.05)$. Similarly, significant differences were seen in group undergoing contralateral testicular torsion for 10 hours then manual detorsion (CP) as compared with the 10-hour torsion group plus dexamethasone 30 minutes before detorsion and manual detorsion 4 hours thereafter $(\mathrm{N})$. This suggests that the administration of dexamethasone may have an effect in suppressing the percentage of IgG levels in the testes whose contralateral side undergoes testicular torsion for 10 hours.

\section{DISCUSSION}

Unilateral testicular torsion is one of the conditions that is often associated with one of the causes of fertility impairment in men. Several studies have shown that under these conditions tissue histologic and biochemical changes take place, both on the torsio side of the testis and the contralateral side that is not affected by the torsion, although this is still controversial. This study aimed to determine the effect of dexamethasone on the number of spermatogonium cells and the production of IgG on the contralateral testis of Wistar strains white rats that received unilateral testicular torsion treatment for $10 \mathrm{~h}$. 
Table 6. Post-Hoc Mann-Whitney U analysis of the comparison of spermatogonium count

\begin{tabular}{lccccc}
\hline $\begin{array}{l}\text { Comparison } \\
\text { between Groups }\end{array}$ & $\mathrm{n}$ & $\begin{array}{c}\text { Median } \\
\text { (Min-Max) }\end{array}$ & VS & $\begin{array}{c}\text { Median } \\
\text { (Min-Max) }\end{array}$ & $\mathrm{p}$ \\
\hline CN VS CP & 9 & $1.01(0.51-47.2)$ & VS & $56.42(46.08-72.86)$ & $0.00^{*}$ \\
CN VS N & 9 & $1.01(0.51-47.2)$ & VS & $27.70(10.03-52.25)$ & $0.00^{*}$ \\
CP VS N & 9 & $56.42(46.08-72.86)$ & VS & $27.70(10.03-52.25)$ & $0.00^{*}$ \\
\hline
\end{tabular}

This study found that contralateral testes in groups of rats subjected to testicular torsion for 10 hours experienced a decrease in spermatogonium cell count compared with no unilateral testicular torsion group with $\mathrm{p}<0.05$. This proves that unilateral testicular torsion may also affect and cause damage to the contralateral testes. Although the exact mechanism is unclear, there are several theories about the cause. Several theories and studies show that ischemia due to torsion in unilateral testis causes reflexes in the blood vessels on the contralateral side, causing local ischemia in the testicular blood vessels, resulting in decreased blood flow on the contralateral side of the unilateral torsion. During these ischemic conditions ATP production decreases due to the limited amount of oxygen. In this condition an increase in intracellular $\mathrm{Ca} 2+$ triggers the conversion of xanthine dehydrogenase to xanthine oxidase which is a superoxide generating enzyme. This causes an increase in free radicals. When manual detection is performed on the side of unilaterally testicular torsion, at nearly the same time on the contralateral side there is also increased blood flow. It is strongly suspected to cause ischemic reperfusion injury that triggers an increase in free radicals that can cause damage to germ cells, such as spermatogonia.

Decreased spermatogonium is also suspected as a result of decreased testosterone due to metabolic stress. When there is a decrease in testosterone levels, Leydig cells increase apoptosis. Decreased testosterone due to ischemia in Leydig cells causes Fas expression on the surface of germ cells, as well as on the surface of Sertoli cells by expressing FasL on the surface of Sertoli cells. The Fas and FasL bond on the germ cell surface causes apoptosis in germinal epithelial cells through Fas Associated Protein with Death Domain (FADD) activation.

This study also showed that the decrease of spermatogonium cells on the contralateral side of the testis with unilateral testicular torsion is thought to be a process of immunity. The autoimmune process is thought to occur as a result of unilateral testicular damage with lengthy torsion followed by immunological damage to the testicular blood barrier that triggers the production of antibodies to the body and then attacks the healthy contralateral testes. When the testicular blood barrier is damaged, the germ cells release proteins that enter the circulation and are recognized by immunocompetent cells as antigens. Furthermore, differentiation and activation of $\mathrm{T}$ cells occurs, possibly secreting various types of cytokines, among them is interleukin 4 (IL-4). IL-4 further induces the activation, proliferation and maturation of $\mathrm{B}$ cells, resulting in the production of antibodies that are likely to induce damage to germinal epithelial cells on the contralateral side. This is also seen in this study. Increased percentage of IgG occurred in group undergoing unilateral testicular torsion for $10 \mathrm{~h}$ and then being subjected to detorsion, compared with that in the non testicular torsion group with $\mathrm{p}$ value $<0.05$.

In this study, the administration of dexamethasone was performed in an attempt to prevent the destruction of contralateral testicular cells in rats with unilateral testicular torsion. The results of this study showed that in groups of rats who had unilateral testicular torsion for $10 \mathrm{~h}$ and were administered with dexamethasone prior to detorsion, compared with the group undergoing unilateral testicular torsion for $10 \mathrm{~h}$ and detorsion only, the dexamethasone group had significantly higher spermatogonium cell count with $\mathrm{p}$ value $<0.05$. This is probably due to the effects of dexamethasone ability of suppressing spermatogonium cell apoptosis. Yazawa et al (2001) found that glucocorticoid hormone can suppress germ cell apoptosis induced by testicular ischaemia.

Dexamethasone administration can also suppress the percentage of immunoglobulin production in this study. It was found that the group undergoing unilateral testicular torsion for $10 \mathrm{~h}$ and manual detorsion had a higher percentage of immunoglobulin $G$ levels than the group undergoing unilateral testicular torsion for $10 \mathrm{~h}$ and receiving dexamethasone prior to manual detorsion. This is probably due to the immunosuppressive ability of dexamethasone. Dexamethasone is thought to inhibit the activation and proliferation of $B$ cells so that its levels decreases. Therefore, in this study we concluded that administering dexamethasone prior to manual detorsion can provide a protective effect on the contralateral testis which undergoes unilateral torsion by preventing germinal apoptosis through the suppression of immune response. 


\section{CONCLUSIONS}

The study concluded that there was a decrease in spermatogonium cells and a significant increase in $\operatorname{IgG}$ levels on the contralateral side of the testes in group undergoing unilateral testicular torsion for 10 hours and detorsion, compared with the group with no unilateral testicular torsion for $10 \mathrm{~h}$ with $\mathrm{p}<0.05$.

There was a decrease in spermatogonium cells and a significant increase in IgG levels on the contralateral side of the testis in group undergoing unilateral testicular torsion for $10 \mathrm{~h}$ and receiving dexamethasone before detorsion compared to non testicular torsion group with $\mathrm{p}<0.05$.

There was also a decrease in spermatogonium cells and a significant increase in $\operatorname{IgG}$ levels on the contralateral side of the testis in the group undergoing unilateral testicular torsion for $10 \mathrm{~h}$ and detorsion compared with the group undergoing unilateral testicular torsion for 10 $\mathrm{h}$ and obtaining dexamethasone prior to detorsion with $\mathrm{p}<0.05$. The administration of dexamethasone may have a protective effect on spermatogonium cell counts on the side of the contralateral side of the testis in group undergoing unilateral testicular torsion for $10 \mathrm{~h}$ before detorsion.

\section{REFERENCES}

Barker K, Raper FP (1964). Torsion of the testis. Br. Journal of Urology 36, 35-41

Doerge RF (1982). Ed. Wilson and Gisvol's textbook of organic and pharmaceutical chemistry. 8th ed. Philadelphia, J.B. Lippincott

Hardjowijoto S (2004). Pengaruh torsio testis unilateral terhadap modulasi respon imun dan peningkatan apoptosis pad testis kontralateral. A dissertation. Surabaya, Universitas Airlangga

Cuckow PM, Frank JD (2000). Version of Record online. BJU International 86, 349-353

Purnomo, BP (2003). Dasar-dasar urologi. Jakarta, Sagung Seto, p 145-148

Saez JM, Morera AM, Haour F, Evain D (1977). Effects of in vivo administration of dexamethasone, corticotropin and human chorionic gonadotropin on steroidogenesis and protein and DNA synthesis of testicular interstitial cells in prepuberal rats. Endocrinology 101, 1256-1263

Sjamsuhidajat R, De Jong W (2004). Buku ajar ilmu bedah. 2nd ed. Jakarta, Penerbit Buku Kedokteran EGC, p 799

Subowo (1993). Immuno biologi. Bandung, Angkasa, $p$ 17-20, 53-57

Turek PJ (1997). Immunopathology and infertility. In infertility in the male. Eds. Lipshultz LI and Howard SS. 3rd ed. Missouri, St Loui, p 305-325 